\title{
Increasing soil fertility as an important factor in ensuring food security of the state
}

\author{
Galina Pyrchenkova ${ }^{1}$, Vladimir Sedikh ${ }^{2,3}$, and Elena Radchenko ${ }^{2 *}$ \\ ${ }^{1}$ Academy of Management of the Ministry of Internal Affairs of Russia, 8 Kosmodemyansky Street, \\ Moscow, 125171, Russian Federation \\ ${ }^{2}$ Federal State Research Institute of the Federal Penitentiary Service of the Russian Federation, 15 A \\ Narvskaya Street, Moscow, 125130, Russian Federation \\ ${ }^{3}$ Federal State Budgetary Educational Institution of Higher Education «Russian State Agrarian \\ University - MSHA named after K. A. Timiryazev», 41 Timiryazevskaya Street, Moscow, 127550, \\ Russian Federation
}

\begin{abstract}
The influence of chicken manure compost with sawdust in doses from 100 to $1000 \mathrm{t} / \mathrm{ha}$ on soil properties was studied on the sodpodzolic soils where the poultry farms of the Moscow region are located. An increase in $\mathrm{pH}$, the humus content, the content of water-soluble forms of NPK in soils and an increase in the complexing capacity of soils were found. The authors define the correlation of the content of mobile forms of heavy metals in the sod-podzolic soils fertilized with poultry droppings with soil $\mathrm{pH}$, the content of humus and mobile phosphates in them. The permissible doses of manure introduced into the soil as fertilizer are determined by the combination of properties, processes and soil regimes, relief, groundwater level, and hydrothermal conditions of the territory. The introduction of droppings into soils contaminated with heavy metals increased their mobility due to complex formation. A positive effect of the use of humates from chicken droppings on the bioproductivity of plants is defined. The article considers the necessity of controlling the quality of the water and air environment when regulating the composition and doses of application of chicken manure compost.
\end{abstract}

\section{Introduction}

There is much domestic research about sustainable agriculture which includes all of the systems and practices necessary to ensure the increase of soil fertility as an important factor of ensuring food security of the state [1 - 4]. The introduction of organic fertilizers into the soil is an important method of increasing soil fertility and crop yield. However, at the same time, water and air pollution occurs, an excess of nitrogen appears in the soils, and the amount of pathogenic microflora increases above the MPC [5]. In some cases, soil and agricultural products are contaminated with nitrates and heavy metals [6].

Issues of soil management and provision of long-term stability and efficiency of agricultural resources are also considered by the foreign scientists [7 - 13]. At the same

\footnotetext{
*Corresponding author :helenr2003@mail.ru
} 
time, one of the priority issues for foreign researchers was the investigation of influence of application and management of poultry litter on the increase of soil fertility [14 - 19].

Nevertheless, it is necessary to define in detail the most economical and effective ways of implementation of each application of innovative methods in agriculture together with the protection of agricultural areas and natural resources.

In this respect it is necessary to develop optimal ways of manure disposal, purposeful change of its composition, and determination of the optimal doses of its application to the soil. However, these techniques differ depending on the combination of soil properties, topography, hydrothermal conditions of the territory, and the biochemical composition of the chicken droppings. This determined the goals and objectives of the work performed. The object of the study was sod-podzolic soils of the Moscow region, mainly of mediumloamy granulometric composition on cover loams, where poultry farms are located. Indepth studies were carried out on the soils of the Petelinskaya poultry farm [3].

\section{Research methods}

The method of the study was to assess the effect of increased doses of chicken droppings introduced into the soil (100-1000 t / ha) on soil properties. The acid-basic properties of soil, content of water-soluble forms $\mathrm{NO}_{3}, \mathrm{NH}_{4}, \mathrm{P}_{2} \mathrm{O}_{5}, \mathrm{~K}_{2} \mathrm{O}$, the number of absorbed bases, content of humus, microbiological activity of soil, concentration of soluble and mobile forms of heavy metals in soils were determined [20]. The optimal doses of manure introduced into the soil were estimated based on the feedback principles.

The effect of increased doses of poultry manure on the IR spectra of soils and the amount of certain functional groups in organic matter were determined by the infrared spectroscopy [6].

The economic efficiency of using manure on the sod-podzolic soils was estimated according to the yield of agricultural crops [2]. On average, broiler chicken droppings contain $1.2-2.7 \%$ of nitrogen, $1-2 \%$ of phosphorus, and $0.6-0.8 \%$ of potassium at natural humidity [3]. The introduction of increased doses of manure into the soil leads to an increase in humus, $\mathrm{pH}, \mathrm{NO}_{3}$ content, to a decrease in Eh, to an increase of heavy metals mobility in soils, to contamination of soils, water and air with pathogenic microflora. At the same time, these components contaminate plant products, meat, milk, manure and after the transformation in the soil and in the aquatic environment - to re-contamination of all the components of the ecological system.

Up to $1.3 \mathrm{t} / \mathrm{s}$ of liquid and gaseous substances are released into the air from the treatment facilities: soot, nitrogen dioxide and oxide, sulfur dioxide, hydrogen sulfide, ammonia, methyl mercaptan, propionic aldehyde, phenol, dimethylamine, dimethyl sulfide.

According to the data obtained, when applying increased doses of manure to soil, the $\mathrm{NO}_{3}$ content in soil samples increases from $43.1 \mathrm{mg} / \mathrm{kg}$ to 72.8 ; basal respiration - from 419 to $900 \mathrm{mcg}$ of $\mathrm{CO}_{2}$ per hour; substrate-induced respiration - from 419 to $900 \mathrm{mcg}$ of $\mathrm{CO}_{2}$ per hour, microbial biomass - from $1602 \mathrm{mcg} / \mathrm{g}$ of soil to 36064 . In the purified water of poultry farms, the increased content of thermotolerant bacteria, common polymorphic bacteria, the content of nitrates in soils can reach $1000 \mathrm{mg} / \mathrm{l}$, water - soluble potassium - 40 $\mathrm{mg} / 100 \mathrm{~g}$.

With the correct agricultural application of large doses of chicken droppings within the permissible limits of the MPC, the chemical composition of rivers and reservoirs also changes. So, for a small river near the Glebovskaya poultry farm, the values are: $\mathrm{pH}=7.8$; 
turbidity -4.2 ; permanganate oxidability $-1.28 \mathrm{mg} / \mathrm{dm} 3$, wherein colimorphic and thermotolerant bacteria are absent.

It is necessary to calculate the changes occurring in the soil depending on the granulometric and mineralogical composition of soil, the capacity of absorption of cations and anions by the soil, the relief, the groundwater level and other parameters of the landscape state.

\subsection{Environmental restrictions on the use of poultry manure in agriculture}

The introduction of high doses of chicken manure into the soil leads to water and air pollution. Studies have shown that the application of manure to the sod-podzolic mediumcultivated soils in doses of more than 100 t/ha result in large-scale emissions to air of carbon dioxide, methane, ammonia, and oxidized nitrogen compounds.

Considerable migration of $\mathrm{NO}_{3}, \mathrm{NH}_{4}$, phosphates, potassium, pathogens, organic compounds in the water near poultry farms has been defined [5]. Thus, according to our data, at a low (50 t/ha) and high (1000 t/ha) dose of manure introduced into the soil, the size of the stems and roots of the biotest under the influence of water extraction from the soil was $3.6 \pm 0.2$ and $2.4 \pm 0.2 \mathrm{~cm}$ - for the stems and $6.7 \pm 0.4$ and $5.5 \pm 0.4 \mathrm{~cm}$ - for the roots, respectively. Under the influence of vapors from the soil the size of the roots of biotest amounted to $6.4 \pm 0.5 \mathrm{~cm}$ and stems to $2.5 \pm 0.2 \mathrm{~cm}$ at low dosage of manure; under the influence of evaporation from soils with a high dose of manure the size of the roots of biotest amounted to $6,3 \pm 0,5$, stems to $1,7 \pm 0,2$.

Under the influence of high doses of manure, there is a change in the mobility of heavy metals in soils. A number of authors note a decrease in the mobility of heavy metals in soils when applying organic fertilizers, which is associated with an increase in the capacity of absorption of cations by soils and the processes of complexation.

According to most authors, organic fertilizers contain insignificant amounts of heavy metals. However, this depends on the methods of obtaining compost, livestock and poultry feed. These indicators vary from year to year and for individual heavy metals. Thus, according to Aristarkhov A. N. (2000) [21], the intake of heavy metals in agrocenoses of the Moscow region was from 20.9 to $123.0 \mathrm{~kg} / \mathrm{ha}$ for $\mathrm{Pb}$, from 87 to $240 \mathrm{~kg} / \mathrm{ha}$ for $\mathrm{Zn}$, and from 7.9 to $23.3 \mathrm{~kg} / \mathrm{ha}$ for $\mathrm{Cd}$ in different years.

Lead enters the soil mainly with lime material (40-42\%) and precipitation (28-35\%), zinc - with organic fertilizers (49-61\%) and precipitation (20-21\%), cadmium - with organic fertilizers $(46-50 \%)$, with lime materials $(20-32 \%)$ and precipitation $(16-26 \%)$, chromium - mainly with organic fertilizers (62-63\%) and lime (34-36\%) (Voitovich N. V., 1997) [22].

However, taking into account the doses of fertilizers, the increase in the gross content of heavy metals in soils, even with intensive chemicalization, is small. It is significant at doses of organic fertilizers above $40 \mathrm{t} / \mathrm{ha}$. According to our data, the introduction of increased doses of chicken manure in the sod-podzolic medium loamy soil up to $50 \mathrm{t} / \mathrm{ha}$ has slightly increased the content of mobile forms of heavy metals in soils (extract $\mathrm{CH}_{3} \mathrm{COONH}_{4}$ with $\mathrm{pH}=4.8$ ), but did not lead to an increase in their content above the MPC. Thus, the iron content increased from $5.1 \mathrm{mg} / \mathrm{kg}$ to 22.5 ; zinc - from 2.6 to 4.1 ; copper - from 0.1 to 0.3 ; lead - from 0.4 to $0.6-0.7 \mathrm{mg} / \mathrm{kg}$.

At the same time, the content of mobile forms of heavy metals in soils has increased differently in the Ap, A2 and B horizons, which is associated with both the granulometric composition and $\mathrm{pH}$ of these horizons, and with the washing type of the water regime. 
At a low dose of chicken manure, the content of mobile forms (extract $\mathrm{CH}_{3} \mathrm{COONH}_{4}$ ) was in $\mathrm{Ap}$ and $\mathrm{B}$ : Fe 5.1 and $21.1 \mathrm{mg} / \mathrm{kg} ; \mathrm{Pb}-0.4$ and $0.3 ; \mathrm{Zn}-2.6$ and $1.9 \mathrm{mg} / \mathrm{kg}$. At a high dose of manure (500 t/ha), the iron content in Ap and B was 21.8 and $29.1 \mathrm{mg} / \mathrm{kg}$; manganese -3.2 and 3.7; zinc -0.9 and 1.4 ; copper -0.1 and 0.2 ; lead- 0.3 and $0.7 \mathrm{mg} / \mathrm{kg}$.

The content of water - soluble forms of heavy metals in soils with an increase in the doses of chicken manure more than $500 \mathrm{t} /$ ha tended to increase $\mathrm{Pb}-$ from 0.09 to $0.14 \mathrm{mg} / \mathrm{l}$; $\mathrm{Cu}$-from 0.01 to $0.05 \mathrm{mg} / \mathrm{l}$; $\mathrm{Zn}$-from 0.03 to $0.07 \mathrm{mg} / \mathrm{l}$. At the same time, in accordance with the solubility diagrams of heavy metal precipitation depending on the $\mathrm{pH}$ of the medium, the zinc content in soil solutions was lower than the solubility of $\mathrm{Zn}(\mathrm{OH})_{2}$, $\mathrm{ZnCO}_{3}, \mathrm{Zn}_{3}\left(\mathrm{PO}_{4}\right)_{2} \cdot 4 \mathrm{H}_{2} \mathrm{O}$; the content of water-soluble copper at $\mathrm{pH}=5-6$ corresponded to the presence of $\mathrm{CuOH}^{+}$и $\mathrm{Cu}(\mathrm{OH})_{2}{ }^{0}$ in solutions, the content of water-soluble lead was lower than the solubility of $\mathrm{Pb}(\mathrm{OH})_{2}$ and is obviously due to lead absorbed by the physicochemical soil absorbing complex of soils. The content of water-soluble forms of copper at different doses of manure application to soils is given in Table 1.

Table 1. Change in the content of water-soluble copper in soils when chicken manure is added to them $\mathrm{mg} / 100 \mathrm{~g}$.

\begin{tabular}{|c|c|c|}
\hline \multirow{2}{*}{ Soil } & \multicolumn{2}{|c|}{ Dose of manure } \\
\cline { 2 - 3 } & $30 \mathrm{t} / \mathrm{ha}$ & $100 \mathrm{t} / \mathrm{ha}$ \\
\hline sod-podzolic & 0.03 & 0.04 \\
meadow chernozem & 0.05 & 0.06 \\
floodplain & 0.02 & 0.03 \\
\hline
\end{tabular}

As it can be seen from the data presented, increasing the doses of manure applied to the soil, leads to some increase in the content of water-soluble copper due to the presence of water-soluble products of decomposition of litter in soil organic substances with complexing ability towards the copper. A similar situation was noted by us near roads - an increase in the content of water-soluble lead compounds when introducing manure into the soil (in the absence of lead in the manure itself).

The content of mobile forms of heavy metals in the studied sod-podzolic soils depended on the $\mathrm{pH}$ of the medium and the degree of humus content:

$\mathrm{Cu}=0,57-0,49 \mathrm{pH}+0,17 \Gamma ; \mathrm{Pb}=0,54-0,51 \mathrm{pH}+0,07 \mathrm{G}$;

$\mathrm{Mn}=0,81-0,62 \mathrm{pH}+0,32 \Gamma ; \mathrm{Cd}=0,69-0,2 \mathrm{pH}+0,48 \mathrm{G}$ at $\mathrm{F}>2,7$.

The mobility of heavy metals in the soils fertilized with manure varies depending on the degree of acidity of the soil and the environment Eh. This is illustrated by the Table 02 data.

Table 2. Displacement of heavy metals from sod-podzolic soils depending on $\mathrm{pH}$ and Eh desorbent, $\mathrm{mg} / 1$.

\begin{tabular}{|c|c|c|c|}
\hline Desorbent & $\mathrm{Pb}$ & $\mathrm{Cu}$ & $\mathrm{Fe}$ \\
\hline $\mathrm{KCl}-0,01 \mathrm{H}$ & $0,15 / 0,21$ & $0,01 / 0,04$ & н.д. $/ 0,30$ \\
$\mathrm{Na}_{2} \mathrm{~S}_{2} \mathrm{O}_{3}-0,01 \mathrm{H}$ & $0,38 / 0,40$ & $0,11 / 4,70$ & $0,09 / 0,70$ \\
$\mathrm{~K}_{2} \mathrm{Cr}_{2} \mathrm{O}_{7}-0,01 \mathrm{H}$ & $0,42 / 0,45$ & $0,50 / 0,71$ & $0,14 / 0,82$ \\
\hline
\end{tabular}

*) in the numerator - when applying low doses of manure (100 t/ ha), in the denominator - at high doses (1000 t / ha).

As it can be seen from the presented data, in soils with the introduction of high doses of manure, the content of mobile forms of heavy metals is higher both: under oxidative conditions $\left(\mathrm{K}_{2} \mathrm{Cr}_{2} \mathrm{O}_{7}\right.$ extract) and recovery conditions ( $\mathrm{Na}_{2} \mathrm{~S}_{2} \mathrm{O}_{3}$ extract). The content of 
mobile acid-soluble and alkaline-soluble compounds of heavy metals increases with increasing doses of poultry manure introduced into the soil. This is illustrated by the data in the following table.

As it can be seen from the presented data, the content of mobile forms of heavy metals increases when high doses of manure are introduced into the soil.

Table 3. Displacement of $\mathrm{Cu}, \mathrm{Zn}, \mathrm{Pb}(\mathrm{mg} / \mathrm{l})$ from sod-podzolic soils by the solutions of desorbents of $0.01 \mathrm{n}$ concentration depending on the doses of chicken manure (in the numerator - the dose of $100 \mathrm{t} /$ ha, in the denominator - $1000 \mathrm{t} / \mathrm{ha}$ ), Ap.

\begin{tabular}{|c|c|c|c|}
\hline \multirow{2}{*}{ Cation } & \multicolumn{3}{|c|}{ Desorbent } \\
\cline { 2 - 4 } & $\mathrm{KC} 1$ & $\mathrm{HC} 1$ & $\mathrm{NaOH}$ \\
\hline $\mathrm{Cu}$ & $00,01 / 0,04$ & $0,02 / 0,08$ & $0,06 / 0,15$ \\
$\mathrm{Zn}$ & $0,02 / 0,09$ & $0,18 / 0,24$ & $0.08 / 0,09$ \\
$\mathrm{~Pb}$ & $0,15 / 0,21$ & $0,27 / 0,30$ & $0,26 / 0,31$ \\
\hline
\end{tabular}

Very high doses of chicken manure increased the content of both water-soluble and mobile forms of heavy metals in soils. This is illustrated by the data in the following table.

Table 4. Dependence of changes in the content of water-soluble and mobile forms of heavy metals on the doses of manure application on soddy-podzolic soils, Ap (mg / l)*.

\begin{tabular}{|c|c|c|c|c|}
\hline Dose of manure & $\mathrm{Cu}$ & $\mathrm{Zn}$ & $\mathrm{Cd}$ & $\mathrm{Pb}$ \\
\hline low $-50 \mathrm{t} / \mathrm{ha}$ & $0,02 / 0,24$ & $0,02 / 0,15$ & $0,01 / 0,05$ & $0,09 / 0,67$ \\
high $-1000 \mathrm{t} / \mathrm{ha}$ & $0,05 / 1,78$ & $0,03 / 4,10$ & $0,02 / 0,06$ & $0,14 / 0,72$ \\
\hline
\end{tabular}

*) in the numerator - the water-soluble form, in the denominator - in the extract KC1 + EDTA.

With an increase in the ionic strength of the desorbents solutions and their complexing ability, the content of heavy metals in the extracts increased $[1,5]$. This is illustrated by the data in the following table.

Table 5. Content of mobile forms of heavy metals in soils depending on the doses of poultry manure (Ap horizon).

\begin{tabular}{|c|c|c|c|c|}
\hline \multirow{2}{*}{ Dose of application } & \multirow{2}{*}{ Extract } & \multicolumn{3}{|c|}{ Content in the extract, $\mathrm{mg} / \mathrm{l}$} \\
\cline { 3 - 5 } & & $\mathrm{Pb}$ & $\mathrm{Cu}$ & $\mathrm{Zn}$ \\
\hline $50-100 \mathrm{t} / \mathrm{ha}$ & $\mathrm{H}_{2} \mathrm{O}$ & 0,09 & 0,02 & 0,02 \\
$500-1000 \mathrm{t} / \mathrm{ha}$ & $-\ll-$ & 0,11 & 0,03 & 0,04 \\
$50-100 \mathrm{t} / \mathrm{ha}$ & $\mathrm{KC} 1-0,1 \mathrm{H}$ & 0,15 & 0,01 & 0,02 \\
$500-1000 \mathrm{t} / \mathrm{ha}$ & $-\ll-$ & 0,19 & 0,03 & 0,03 \\
$50-100 \mathrm{t} / \mathrm{ha}$ & $\mathrm{KC} 1,0,1 \mathrm{H}+0,01 \mathrm{M}$ EDTA & 0,67 & 0,24 & 0,75 \\
$500-1000 \mathrm{t} / \mathrm{ha}$ & $-\ll-$ & 0,68 & 0,82 & 2,20 \\
\hline
\end{tabular}

The content of mobile forms of heavy metals in soils depends on the complexing ability of desorbents, taking into account the effects of protonation and hydrate formation. This is illustrated by the data in the following table. 
Table 6. Change in the content of mobile forms of $\mathrm{Cu}, \mathrm{Zn}, \mathrm{Fe}, \mathrm{Pb}, \mathrm{Cd}$ in the sod-podzolic soils fertilized with poultry mature (1000 t/ha), depending on the complexing ability of the desorbent $(\mathrm{mg} / \mathrm{l}), \mathrm{Ap}$.

\begin{tabular}{|c|c|c|c|c|c|}
\hline Extract & $\mathrm{Pb}$ & $\mathrm{Cd}$ & $\mathrm{Cu}$ & $\mathrm{Zn}$ & $\mathrm{Fe}$ \\
\hline $\mathrm{KC} 1,0,1 \mathrm{H}$ & 0,45 & 0,05 & 0,06 & 0,18 & 0,20 \\
+ EDTA & 0,72 & 0,06 & 1,78 & 4,08 & 9,83 \\
$+\mathrm{H}_{2} \mathrm{C}_{2} \mathrm{O}_{4}$ & 0,53 & 0,06 & 0,15 & 0,82 & 2,67 \\
+ lemon acid & 0,48 & 0,05 & 0,19 & 1,20 & 22,82 \\
\hline
\end{tabular}

When assessing the dependence of the displacement of heavy metals from soils on the complexing ability of the desorbent according to 15 formulas, it was found that the best description of the dependence basically corresponds to the equation $\mathrm{Y}=\mathrm{A}+\mathrm{B}^{\mathrm{X}}$.

High doses of manure introduced into the soil increased the content of complex compounds of polyvalent cations in soils, enhancing the proportion of their negatively charged compounds. So, with an average dose of mature and a high dose of mature, the content of $\mathrm{FeL}^{\mathrm{n}+}$ was respectively $2.8 \pm 0.8 \mathrm{mg} / 1$ and $1.4 \pm 0.4 \mathrm{mg} / 1$, and the content of $\mathrm{FeL}^{\mathrm{n}-}$ was $2.9 \pm 0.5$ and 3 , respectively, $1 \pm 0.9 \mathrm{mg} / 1$. The content of mobile forms of heavy metals is closely related to soil properties, which is also noted for the sod-podzolic soils, where poultry farms are located in the Moscow region. This is illustrated by the data in the following table.

Table 7. Dependence of the displacement of $\mathrm{Zn}, \mathrm{Cu}$, Fe from the sod-podzolic soils fertilized with poultry mature on the complexing ability $(\mathrm{X}) ; \mathrm{Y}=\mathrm{A}+\mathrm{B}^{\mathrm{X}}$.

\begin{tabular}{|c|c|c|}
\hline Cation & Regression equation & Index of correlation \\
\hline $\mathrm{Zn}$ & $\mathrm{E}=0,10+1,15^{\mathrm{X}}$ & 0,84 \\
$\mathrm{Cu}$ & $\mathrm{E}=0,03+1,08^{\mathrm{X}}$ & 0.58 \\
$\mathrm{Fe}$ & $\mathrm{E}=0,17+1,18^{\mathrm{X}}$ & 0,98 \\
\hline
\end{tabular}

However, for different heavy metal ions, desorption was adequately described by different equations:

for zinc, $\mathrm{Y}=\mathrm{AH} /(\mathrm{B}+\mathrm{X}) ; \mathrm{Y}=0.42 \mathrm{X} /(), 35+\mathrm{X}) ; \mathrm{r}=0.85$;

for iron $\mathrm{Y}=3.5 \mathrm{X} /(2.1+\mathrm{X}) ; \mathrm{r}=0.91$;

for copper $\mathrm{Y}=\mathrm{A} \cdot \exp (0.08 \mathrm{X}) ; \mathrm{r}=0.58$.

For the soils of the Krasnopolyanskaya poultry farm, the dependence of the content of mobile zinc on the properties of soils was described by the following equation:

$\mathrm{Zn}=-4.6+3.9$ humus $-4.3 \mathrm{~S}+3.9 \mathrm{pH}+0.01 \mathrm{P}_{2} \mathrm{O}_{5} \mathrm{r}=0.80 ; \mathrm{F}=3.6$.

Table 8. Dependence of the content of mobile forms of heavy metals on the properties of the sodpodzolic soils of the Kuntsevskaya poultry farm: $\mathrm{E}=\mathrm{f}$ (humus, $\left.\mathrm{S}, \mathrm{pH}, \mathrm{P}_{2} \mathrm{O}_{5}\right)$; $\mathrm{E}=\mathrm{f}\left(\mathrm{X}_{1}, \mathrm{X}_{2}, \mathrm{X}_{3}, \mathrm{X}_{4}\right.$ ).

\begin{tabular}{|c|c|c|c|}
\hline $\begin{array}{c}\text { Calculated } \\
\text { dependence }\end{array}$ & Regression equation & $\mathrm{R}$ & $\mathrm{F}$ \\
\hline $\mathrm{Ni}=\mathrm{f}(\mathrm{X})$ & $\mathrm{Ni}==14,0-1,4 \mathrm{X}_{1}+1,9 \mathrm{X}_{2}+0,8 \mathrm{X}_{3}+0,001 \mathrm{X}_{4}$ & 0,9 & 3,1 \\
$\mathrm{Cu}=\mathrm{f}(\mathrm{X})$ & $\mathrm{Cu}=-18,1-3,3 \mathrm{X}_{1}+1,3 \mathrm{X}_{2}+2,3 \mathrm{X}_{3}+0,001 \mathrm{X}_{4}$ & 0,99 & 26,5 \\
$\mathrm{Zn}=\mathrm{f}(\mathrm{X})$ & $\mathrm{Zn}=-7,2+1,1 \mathrm{X}_{1}+0,5 \mathrm{X}_{2}-0,5 \mathrm{X}_{3}-0,01 \mathrm{X}_{4}$ & 0,6 & 0,4 \\
\hline
\end{tabular}

As it can be seen from the presented data, the content of mobile forms of nickel, copper, zinc increases with the increasing of the soil absorption capacity (S) and weakly depends on the content of mobile phosphates. The content of mobile forms of nickel and copper has increased with an increase in $\mathrm{pH}$ (below 7.0), and the content of zinc has decreased. 
However, for the sod-podzolic soils of different poultry farms, the considered dependences were different, which is due to the different combination of soil properties.

The considered dependences were also different for paired correlations. According to the obtained results, the dependence of the content of mobile forms of zinc on the combination of the properties of the studied soils was characterized by the correlation coefficient of $\mathrm{r}=0,77$ at $\mathrm{F}=3,6$. At the same time, the dependencies of the content of mobile zinc on the content of humus, number of absorbed bases, $\mathrm{pH}$, the content of mobile phosphates were characterized by the correlation coefficients respectively 0,$61 ; 0,37 ; 0,73$ и 0,32 .

In the presence of heavy metals in the soil, they enter plants, then enter the body of animals and birds with food, and with droppings and manure again come back into the soil [1].

\subsection{Ways to optimize landscape components when using poultry droppings in agriculture}

Studies have shown that reasonable doses of the poultry manure introduced into the sodpodzolic medium loamy soils of the Moscow region significantly increase soil fertility, soil score and crop yield. However, for the soils fertilized with high doses of manure, it is necessary to define their own models of soil fertility and modified methods for increasing the yield of agricultural crops and soil fertility.

Table 9 shows the change in the humus content in the sod-podzolic soils when high doses of manure are introduced into them.

Table 9. Humus content in sod-podzolic soils at different doses of chicken manure application.

\begin{tabular}{|c|c|c|c|}
\hline Horizon, & \multirow{2}{*}{ Humus, \% } & \multicolumn{2}{|c|}{ Humus, \% in extract $\mathrm{Na}_{4} \mathrm{P}_{2} \mathrm{O}_{7}$} \\
\cline { 3 - 4 } dose of manure & & $\mathrm{pH}=4$ & $\mathrm{pH}=7$ \\
\hline $30 \mathrm{t} / \mathrm{ha}$ & $3,5 \pm 0,2$ & 0,5 & 0,7 \\
$\mathrm{~A}_{0} \mathrm{~A}_{1}-0-14$ & $2,9 \pm 0,2$ & 0,5 & 0,7 \\
$\mathrm{~A}_{1}-14-32$ & & & 0,2 \\
$500 \mathrm{t} / \mathrm{ha}$ & $4,2 \pm 0,1$ & 0,5 & 0,5 \\
$\mathrm{Ap}-0-37$ &
\end{tabular}

As it can be seen from the presented data, with increasing doses of poultry droppings introduced into the soil, the content of humus in soils increases. At a dose of $1000 \mathrm{t} / \mathrm{ha}$, it was $6.3 \pm 0.2 \%$.

At the same time, when large doses of manure were introduced into the soil, not only the humus content in the soil increased, but also its homogeneity, the degree of condensation, and the ratio of functional groups changed. According to the data obtained by us, when doses of more than 500 t/ha are applied to the sod-podzolic medium-loamy soil, less homogeneous organic matter is formed, which is probably due to incomplete decomposition of mature in the soil. This was also shown by the derivatography data. At the same time, when very large doses of manure are introduced into the soil, the proportion of aromatic compounds in humus decreases. This was also shown by infrared spectroscopy data. At moderate doses of mature application, the absorption ratio at $1600 \mathrm{~cm}-1$ and 3500 $\mathrm{cm}-1$ was 0.7 in humus, and at high doses -0.5 .

The introduction of manure into the soil also leads to a change in the complexing ability of soil solutions. When applying low and medium doses of manure to the soil, the complexing ability of soil solutions was higher in the $\mathrm{A}_{2} \mathrm{~B}$ and $\mathrm{B}$ horizons, compared to $\mathrm{Ap}$, 
which is associated with the migration of fulvic acids to these horizons. At a high dose of manure, the complexing ability with respect to copper was higher in the Ap and was obviously due to the organic compounds of the manure itself.

An increase in the doses of manure introduced into the soil affected the biological activity of water extract from the soil and evaporation from the soil. Thus, at low and high doses of manure introduced into the soil, the size of biotest stems was $3.6 \pm 0.2$ and $2.4 \pm 0.2$, respectively; roots $-6.7 \pm 0.4$ and $5.5 \pm 0.4 \mathrm{~cm}$. The size of the roots of biotest-watercress was $2.5 \pm 0.2 \mathrm{~cm}$ under the influence of soil evaporation at a low dose of manure and $1.7 \pm 0.2 \mathrm{~cm}$ at a high dose.

The introduction of chicken manure into the sod-podzolic soils did not significantly change the $\mathrm{pH}$ of the water suspension. When applying a low and medium dose of litter up to $100 \mathrm{t} / \mathrm{ha}$ and a high dose of $500-1000 \mathrm{t} / \mathrm{ha}$, the $\mathrm{pH}\left(\mathrm{H}_{2} \mathrm{O}\right)$ value was $7.3 \pm 0.1$ and $7.2 \pm 0.4$, respectively, in Ap; $6.6 \pm 0.3$ and $6.8 \pm 0.1$ in $A_{2} B$; and $5.8 \pm 0.1$ and $5.7 \pm 0.2$ in $B$.

The introduction of manure into the sod-podzolic soils of Petelinskaya poultry farm also led to a sharp increase in mobile phosphates in soils (up to $1180 \mathrm{mg} / \mathrm{kg} \mathrm{P}_{2} \mathrm{O}_{5}$ in mediumloamy soils and up to $1220 \mathrm{mg} / \mathrm{kg}$ in light - loamy soils). At the same time, when large doses of manure were introduced into the soil, the content of Ca-phosphates of group 1, to a lesser extent of phosphates of groups 2 and 3, has increased in the soils, and the content of iron and aluminum phosphates has decreased.

\section{Discussion}

The positive influence of the introduction of manure on the yield of agricultural crops is confirmed by the research data. Bobrenko N.A. et al (2019) [23] proved that the introduction of chicken droppings was also effective on the meadow chernozem soils of the Omsk region. The greatest return was observed when applying $12 \mathrm{t} / \mathrm{ha}$ for white cabbage. At the same time, the increase in yield was $23.1 \mathrm{t} / \mathrm{ha}$, or $40.5 \%$ of the control. The utilization rate of biophilic elements was $\mathrm{N}-35 \%, \mathrm{P}_{2} \mathrm{O}_{5}-41 \%, \mathrm{~K}_{2} \mathrm{O}-88 \%$. The payback of 1 ton of chicken manure was 1.92 ton of manure.

A number of factors influence the biological productivity of the land. Moreover, the weight (degree) of the influence of individual factors on the yield is different. So, according to A.V. Tingaev. and Malyutina L.A. (2016) [24], when poultry manure from 10 to $20 \mathrm{t} / \mathrm{ha}$ was introduced into the soil, a significant increase in the yield of spring soft wheat "Omskaya-28" was observed. The $\mathrm{pH}(\mathrm{KCl})$ value of the soils was 5.8; $\mathrm{pH}\left(\mathrm{H}_{2} \mathrm{O}\right)=6.8$; humus content in soils $-5.5 \%$. The content of mobile phosphorus $-217.7 \mathrm{mg} / \mathrm{kg}$, mobile potassium $-142.7 \mathrm{mg} / \mathrm{kg} ; \mathrm{NO}_{3}-7.2 \mathrm{mg} / \mathrm{kg}$. At the same time, the proportion of manure application influenced the yield by $29.5 \%$. The share of the combined effect of manure doses and soil properties on the yield was $95.5 \%$.

\section{Conclusions}

From our point of view, the optimal doses of manure introduced into the soil depend on its type, conditions of feeding and keeping chickens, composition and ratio of compost components [2]. The research proves that the optimal and permissible doses of manure introduced into the soil depend on the ecological state of the territories, limits of soil, water and air pollution, on the intensity of development of soil-forming processes, the combination of properties, processes and soil regimes. The correct use of poultry manure in 
agriculture is an important technique for improving soil fertility and crop yields. It is also an important factor of providing food security of the state. However, this requires preliminary composting of manure and a reasonable determination of the doses of its optimal introduction, depending on the combination of soil properties, processes and regimes occurring in the soils, and the combination of all components of farming systems.

According to our data, the maximum dose of application of manure with sawdust to the soil to increase productivity is approximately 30-60 t/ha. The maximum dose of this compost for manure disposal reaches $1000 \mathrm{t} / \mathrm{ha}$, taking into account environmental restrictions. The recommended permissible doses of dry chicken manure are $20 \mathrm{t} / \mathrm{ha}$, and on phosphated soils - minus $10 \%$ of the phosphate balance. In greenhouse soils, manure is introduced up to $30 \%$ of the mass, i.e. up to $1000 \mathrm{t} / \mathrm{ha}$. When preparing compost from droppings, the $\mathrm{C} / \mathrm{N}$ ratio in it is taken into account. The nitrogen content in manure is up to $2 \%$ by weight. At an application rate of $100 \mathrm{t} / \mathrm{ha}$, the input of $\mathrm{NO}_{3}$ is up to $700 \mathrm{mg} / \mathrm{kg}$ of soil at $\mathrm{MPC}=130$. However, taking into account the migration of $\mathrm{NO}_{3}$ and its consumption by plants in a year, a concentration of $<200 \mathrm{mg} / \mathrm{kg}$ in the soil is possible. A single dose of $100 \mathrm{t} /$ ha of dropping manure into the soil increases the content of mobile phosphates in the soil by $10 \mathrm{mg} / 100 \mathrm{~g}$.

To inactivate pathogenic microorganisms in the soil, it is necessary to pre-compost the manure. The duration of composting is determined by a combination of soil properties and hydrothermal conditions of the territory, anti-pathogenic capacity of soils. According to our data, when regulating the composition and doses of compost from manure, it is necessary to additionally take into account the granulometric composition of soils, parent rock, relief, groundwater level, proximity to the river when controlling the quality of the water and air environment. We could state, that in soddy-podzolic soils fertilized with large doses of manure, the content of mobile compounds of heavy metals correlated with $\mathrm{pH}$, Eh, and the content of humus and mobile phosphates. When applying manure with fertilizers together, the sequence of application to the soil is important: first, manure, then fertilizer. When disposing of droppings at a dose of $1000 \mathrm{t} / \mathrm{ha}$ after the introduction of droppings, it is recommended to sow the quinoa for the first 2 years, followed by feeding it to livestock. The use of humates from chicken manure also had a positive effect on the development of plants.

\section{References}

1. V.I. Savich, S.P. Torshin, S.L. Belopukhov, V.A. Sedykh, Agroecological assessment of organo-mineral complex compounds of soils (OOO Megaprint, Irkutsk, 2017)

2. V.I. Savich, A.E. Sorokin, V.V. Gukalov, S.I. Barshadskaya, International Agricultural J., 1, 83-86 (2020)

3. V.A. Sedykh, Environmental assessment of the use of poultry manure in agriculture on the soils of the taiga-forest zone (RSAU-Moscow Agricultural Academy, Moscow, 2013)

4. V.I. Titova, L.K. Sedov, E.V. Dabakhova, Industrial poultry farming and ecology. Experience of coexistence (VVAGS, N. Novgorod, 2004)

5. V.A Sedykh, V.I Savich, P.N. Balabko, Soil-ecological monitoring (RSAU-Moscow Agricultural Academy, VNIIA, Moscow, 2013)

6. S.L Belopukhov, V.I. Savich, R.F. Baibekov, Agrofizika, 1, 1-8 (2020) 
7. K.M. Tuğrul, Soil Management in Sustainable Agriculture, Sustainable Crop Production (IntechOpen, 2019), doi: 10.5772/intechopen.88319.

8. J. D. Phillips, Soil Science, 182(4), 117-127 (2017), doi: 10.1097/SS.0000000000000204.

9. P. Lavelle, A. Spain, M. Blouin, et al., Soil Science, 181(3/4), 91-109, (2016), doi: 10.1097/SS.0000000000000155.

10. S. Jia, X. Yang, J. Zhang, G. Li, Soil Science, 179(4), 211-219 (2014), doi: 10.1097/SS.0000000000000060.

11. F. Nicholson, A. Bhogal, M. Taylor, et al., Soil Science, 183(3), 89-98 (2018), doi: 10.1097/SS.0000000000000239.

12. W. Dong, X. Zhang, H. Wang, et al., PLoS ONE, 7(9), e44504 (2012) https://doi.org/10.1371/journal.pone.0044504.

13. D. Tilman, C. Balzer, J. Hill, and B. L. Befort, PNAS, 108(50), 20260-20264 (2011) doi.org/10.1073/pnas.1116437108.

14. O.Ugochukwu, M. U. Orji, A. S. Nwankwegu, et al., European Journal of Experimental Biology, 6(4), 62-68 (2016) Available from: https://www.researchgate.net/publication/303721936_Effect_of_Chicken_droppings_a mendment_on_bioremediation_of_crude_oil-polluted_soil.

15. R. Pinto, L. M. Brito, J. Coutinho, Biological Agriculture and Horticulture, 33(4), 1-16, (2017), doi: 10.1080/01448765.2017.1347521.

16. N.S. Bolan, A.A. Szogi, T. Chuasavathi, et al., Uses and Management of Poultry Litter, 673-698 (2019), doi.org/10.1017/S0043933910000656.

17. M.W. Shepherd Jr., P. Liang, X. Jiang, et al., J. Appl. Microbiol., 108(6), 2067-76 (2010), https://doi.org/10.1111/j.1365-2672.2009.04610.x.

18. K.J. Barker, J.L Purswell, J.D. Davis, et al., International Journal of Poultry Science, 1.9 (1.10) (2010), Available from: https://pubag.nal.usda.gov/catalog/42045.

19. A.E. Ghaly, M. Alhattab, American Journal of Environmental Sciences, 9(2), 88-102 (2013), ISSN:1553-345X.

20. V.I. Savich, O.D. Sidorenko, L.V. Mosina, et al., International Agricultural J., 1, 3242 (2019)

21. A.I. Aristarkhov, Optimization of plant nutrition and the use of fertilizers in agroecosystems (TsINAO, Moscow, 2000)

22. N.A. Bobrenko, N.V. Goshan, V.P. Kormin, A.T. Schmidt, Fertility, 1, 37-40 (2019)

23. A.V. Tingaev, L.A. Malyutina, Bulletin of Altai State Agrarian University, 10, 24-29 (2016) 